\title{
Lieutenant-Colonel Vincent Crane Richmond, O.B.E., Fellow
}

Lieutenant-Colonel Vincent Crane Richmond was born on January 2 ist, 1893, and was educated at the Royal College of Science. Before the war he was an engineer to Messrs. S. Pearson and Sons, engaged on physical and structural problems in connection with dock construction. In I9I5 he joined the Royal Naval Air Service and was chiefly concerned with the construction of non-rigid airships. He went to Germany in 1920 with the Inter-Allied Commission of Control, and was for part of the time in charge of the Naval SubCommission for the surrender of airships and seaplanes. In I92 I he was appointed to the Airship Research Department at the Air Ministry, and for two years was engaged on research problems connected with rigid airship construction. In 1923 he became a lecturer on airship design and construction at the Imperial College of Science. In 1924 he was appointed the officer in charge of design and research at the Royal Airship Works, and from that time was concerned chiefly with the design of R.Ior. In $193^{\circ}$ he was appointed Assistant Director (Technical) of Airship Devèlopment.

Lieut.-Colonel Richmond joined the Society in 1920 and became a Fellow in 1929. In $19^{2} 3$ he was awarded the R.38 Memorial Prize for his joint paper with Major Scott, entitled "A Detailed Consideration of the Effect of Meteorological Conditions on Airships."

He read a number of papers before the Society on the development of the rigid airship, which are classic.

Lieutenant-Colonel Richmond was a man of great personal charm and modesty. As the one chiefly responsible for the design of $R$. ror he was subjected to much criticism, much ill-informed, and he felt his position keenly in that it prevented him from replying. He had an extraordinarily sound judgment and a great breadth of view, and he was always ready to listen to sound criticism and to benefit by it. His papers read before the Society were models of what papers should be. Richmond rose to the high position he held by sheer ability and persistence of character. Richmond took every single precaution he knew to ensure the safety of the great ship which was largely the creation of this genius, and by his loss airships have lost one who will go down in aeronautical history as one of the great pioneers of airship development.

\section{Squadron-Leader Frederick Michael Rope, Associate Fellow}

Squadron Leader Frederick Michael Rope was born in 1888 and educated at Shrewsbury School and Birmingham University. Until 1912 he was an engineer to the British Electric Plant Company, Alloa. In I9I 3 he was employed on locomotive engineering on the Brighton Railway, and in 1915 he joined the Royal Naval Air Service. He served at the Capel and Kingsnorth Air Stations and later as staff officer in the Department of the Director of Research. At CapeI he was responsible for engines of the S.S. and coastal airships and at Kingsnorth for similar work and engine accessories and in charge of wind tunnel work. From 192 I-1924 he was Technical Staff Officer at Air Headquarters, Iraq, and on his return to England he was appointed to the Royal Airship Works, at Cardington. Squadron Leader Rope joined the Society as an Associate Fellow in 1919.

Of a singularly quiet disposition he achieved what he wanted from those above or below him by sheer quiet charm and determined constancy of purpose.

He was a remarkably steady experimenter and observer in flight, a quality rather rare in those of such active inagination.

His inventions contributed greatly to the success of the ship. He could define the requirements exactly and grasped the mechanical principles of design 
so clearly that almost all his designs, even those of startling novelty, were right the first time or required only correction in detail.

Beyond his refusal to claim credit for what he had done, one found it difficult to get him to admit credit.

His one test for a thing-technically or morally-was whether it was right.

Of all the good airship men who have been lost he leaves a gap which will be most difficult to fill.

\section{Major Percy Bishop, M.B.E., Associate Fellow}

Percy Bishop was born in 1888 and educated at Kendrick School, Reading, at the Regent Street Polytechnic, and Sheffield University. $\mathrm{He}$ was apprenticed to Clement Talbot, Ltd., and later served with the Sheffield Simplex Company and with D. Napier and Sons, Ltd. He joined the Royal Aircraft Factory in I9I 2 as a designer and afterwards as chief inspector. In I915 he received a commission in the Royal Flying Corps. He was awarded the M.B.E., both civil and military, in I9I9 in recognition of his services. He continued with the Directorate of Aeronautical Inspection and became Chief Inspector, Aircraft.

Major Bishop was an active and keen member of the Society and served on one of its most important committees of Council, the Grading Committee. Fe was elected an Associate Fellow in 1918.

The following is an abstract from the Times of a tribute paid to Major Bishop by Dr. A. P. Thurston, a personal friend of long standing :-

"As Chief Inspector of Aircraft in the Aeronautical Inspection Directorate, Bishop was known and respected by the heads of every works throughout the land producing material or parts used in or in connection with aircraft. $\mathrm{He}$ was a Berkshire man of typical yeoman stock. His chief characteristics were an intense and unfailing kindness, and an understanding of men, coupled with loyalty and highly efficient practical knowledge of automobile and aeronautical engineering. This knowledge was gained in the works of Clement Talbot, the Sheffield Simplex, D. Napier and Sons, and the Royal Aircraft Factory. He possessed also the shrewdest common sense, and it is no secret that his advice was often sought by those in high authority as well as by leading manufacturers.

"His interest in aeronautics began in I9IO, when he attended a course of my lectures at Sheffield University. On the outbreak of war he was placed in charge of the Inspection Department of the Royal Aircraft Factory, at Farnborough, where his ability was soon recognised by the officers of the Military Aeronautics Directorate. During this period he invented various scientific instruments for accurately gauging aeroplane parts, and wrote a paper which has become a classic.

"He was essentially an aeroplane man-that is, he believed in heavier-thanair craft-but, such was his devotion to duty, he took every possible step to hecome acquainted with the construction and operation of airships. He attended as one of the British representatives the Fifth International Conference on Aeronautics at the Hague." 